\title{
ISTOTA I ZNACZENIE NARZĘDZI CSR W OPINII ZARZĄDZAJĄCYCH BANKAMI SPÓŁDZIELCZYMI
}

\author{
Marta Idasz-Balina \\ Katedra Finansów \\ Szkoła Główna Gospodarstwa Wiejskiego w Warszawie
}

\begin{abstract}
Abstrakt. Celem badań było przedstawienie rozwiązań wykorzystywanych przez banki spółdzielcze w realizacji zasad związanych z ideą społecznej odpowiedzialności biznesu (CSR) oraz ich ważności w opinii zarządzających bankami spółdzielczymi. Badania swoim zakresem objęły 140 banków spółdzielczych, co stanowiło 24,6\% wszystkich banków spółdzielczych funkcjonujących w Polsce według stanu na dzień 30 czerwca 2016 r. Na podstawie przeprowadzonych badań stwierdzono, że banki spółdzielcze wspierają i realizują działania związane ze społeczną odpowiedzialnością biznesu. Ponadto ankietowani wskazali, że najważniejszą formą komunikacji ze społecznością lokalną jest sponsoring, a banki spółdzielcze oprócz tradycyjnych narzędzi CSR wykorzystują także liczne dodatkowe narzędzia, które w opinii zarządzających są istotne w prowadzeniu przez nie działalności.
\end{abstract}

Słowa kluczowe: CSR, społeczna odpowiedzialność biznesu, bank spółdzielczy

\section{WSTĘP}

Koncepcja społecznej odpowiedzialności biznesu jest coraz częściej poruszaną kwestią w sferze politycznej, społecznej i gospodarczej. Powszechny nacisk na zmniejszanie kosztów wytworzenia czy też pracy powoduje negatywne działania, jakimi są: łamanie praw człowieka, zanieczyszczenie środowiska naturalnego czy też dążenie do zysku za wszelką cenę. Tempo życia oraz zmieniające się warunki konkurowania na rynku, zmuszają przedsiębiorstwa do wewnętrznych zmian przystosowawczych. Spowodowało to, że w ostatnich latach w Polsce można 
zaobserwować dużą dynamikę w rozwoju społecznej odpowiedzialności biznesu (CSR), która staje się nieodłączną częścią strategii biznesowej.

Interdyscyplinarny charakter tej idei pozwala na spojrzenie na przedsiębiorstwo z nowej, nie tylko ekonomicznej, perspektywy oraz sposób jego zarządzania [Balina 2014, s. 51-60]. Koncepcja ta, pozwala na zbudowanie zaufania oraz nawiązanie lepszego dialogu z klientami. Według badań, aż 42\% Polaków stwierdziło, że firmy funkcjonują nie tylko po to by zarabiać, ale też podejmować działania na rzecz środowiska i społeczności. Ponadto 51\% badanej populacji sądziło, że produkty i usługi firm, które angażują się w działania na rzecz społeczeństwa, są lepsze jakościowo niż produkty i usługi firm niepodejmujących takich działań SGS Polska 2013, s. 2-3].

Ostatnio także sektor bankowy coraz częściej stosuje się do zasad CSR, co pozwala na osiągnięcie długofalowego rozwoju. Banki, jako instytucje zaufania publicznego, przy realizacji celu ekonomicznego nie mogą zapomnieć o obowiązkach wynikających ze społecznej odpowiedzialności biznesu. Klienci powinni postrzegać ich działania jako potrzebne i przydatne w przyszłości. Nie jest to proste, gdyż jak zauważył Filek łatwiej wielokrotnie powiedzieć, jak należy postępować, niż czynić to codziennie, a szczególne wtedy, kiedy takie postępowanie wymaga dodatkowego wysiłku i kiedy pojawia się pokusa zminimalizowania tego wysiłku przez drogę na skróty. Inną przyczyną jest rozbieżność między poziomem społecznym a poziomem ekonomicznym społeczeństwa. Im większy rozdźwięk, tym trudniej wdrożyć strategię CSR [Filek 2008, s. 64].

Banki spółdzielcze są podmiotami ekonomii społecznej, które już od czasu swego powstania realizują koncepcję CSR [Juszczyk, Balina 2016, s. 27-43]. W sektorze bankowości spółdzielczej koncepcja CSR jest realizowana względem wszystkich podmiotów współpracujących z bankami: klientów, członków, pracowników i społeczności lokalnych [Idasz-Balina, Balina, s. 69-79]. Idea CSR jest analogiczna ze strategią lizbońską, której celami są wprowadzenie innowacji, tworzenie nowych miejsc pracy, wzrost gospodarczy oraz ochrona środowiska.

\section{ZAGADNIENIA METODYCZNE}

Wśród banków spółdzielczych można zaobserwować wprowadzenie wielu nowych działań związanych z realizacją koncepcji społecznej odpowiedzialności biznesu. Oznacza to, że działania te prawdopodobnie przyczyniły się do poprawy wizerunku banków oraz są dobrze odbierane przez ich klientów. Głównym celem badań było przedstawienie rozwiązań wykorzystywanych przez banki spółdzielcze do realizacji zasad związanych z ideą społecznej odpowiedzialności biznesu oraz określenie ich ważności w opinii zarządzających bankami spółdzielczymi. 
Do realizacji głównego celu badań wykorzystano źródła pierwotne, uzyskane z przeprowadzonej ankiety, oraz przegląd literatury przedmiotu. Respondentami byli zarządzający bankami spółdzielczymi na szczeblu członka zarządu. Ankieta została przeprowadzana w drugiej połowie 2016 roku. Formularz ankiety został rozesłany drogą mailową do 565 banków spółdzielczych w Polsce, przy czym odpowiedzi uzyskano z 140 banków. Badane jednostki udzielały odpowiedzi na temat stosowanych form CSR, daty wprowadzenia rozwiązania oraz stopnia ważności danego działania z punktu widzenia zarządzających bankami. W pytaniach zamkniętych respondenci mogli wskazywać więcej niż jedną formę prowadzenia działań CSR w ich banku. W pytaniach dotyczących określenia znaczenia danego rozwiązania w działalności banku spółdzielczego, którym zarządzali ankietowani, mieli oni do wyboru pięciostopniową skalę, gdzie 1 oznaczało najmniej ważny a 5 najważniejszy element.

Analizę przeprowadzono również w ramach wydzielonych kwartyli według wartości aktywów banku, co oznacza, że w kwartylu I znajdowało się 25\% banków, które charakteryzowały się najniższym poziomem analizowanego kryterium, w kwartylu IV znajdowało się 25\% banków o najwyższym poziomie danego kryterium, kwartylu II znajdowało się 25\% banków o poziomie aktywów ogółem większym niż banki z kwartyla I ale mniejszym niż wartość mediany aktywów ogółem badanych banków. Kwartyl III natomiast zawierał pozostałe 25\% badanej populacji, czyli podmioty charakteryzujące się wartościami pośrednimi między kwartylem II i IV.

\section{SPOŁECZNA ODPOWIEDZIALNOŚĆ W SEKTORZE BANKOWYM}

Bank jest to podmiot gospodarczy, który na podstawie zezwolenia władz nadzorczych, prowadzi działalność we własnym imieniu i na własny rachunek. Jego działalność polega przede wszystkim na przyjmowaniu depozytów (lub innych środków powierzonych pod jakimkolwiek tytułem zwrotnym) i udzielaniu kredytów lub wydawaniu pieniądza elektronicznego. Ze względu na funkcje głównym celem banku nie może być maksymalizacja zysku, ale powinny być to również instytucje zaufania publicznego.

Działalność banków wywiera duży wpływ na gospodarkę i społeczeństwo. Społecznie odpowiedzialne zarządzanie bankiem jest trudną kwestią, gdyż często oczekiwania interesariuszy względem banków są rozbieżne. Do grupy interesariuszy (stakeholders) instytucji bankowych zalicza się: pracowników banku, klientów, akcjonariuszy oraz społeczeństwo w obrębie, którego działa dana instytucja. Przykładem rozbieżności interesów może być sytuacja, w której klient, chcąc realizować swe plany ekonomiczne, chce pozyskać kredyt. Bank w tej sytuacji może udostępnić środki na realizację celów klienta, jednak często jest zmuszony 
od odmowy lub zmniejszenia wymiaru kredytu. Klienci banków, deponując swe środki, oczekują bezpieczeństwa oraz wysokiego oprocentowania, natomiast kredytobiorcy liczą na niskie oprocentowanie, długi okres kredytowania oraz brak kosztownego zabezpieczenia. Przedsiębiorstwa bankowe są zmuszone godzić oczekiwania tych grup interesariuszy, jednocześnie uwzględniając oczekiwania właścicieli, którzy liczą na pomnożenie zainwestowanego kapitału.

Banki jako instytucja zaufania publicznego odgrywają szczególną rolę w systemie gospodarczym. Wynika to z funkcji, jakie instytucje bankowe pełnią [Korenik 2009, s. 13]:

- funkcja komercyjna jako podmiotu rynkowej sfery gospodarki, którego aktywność jest nastawiona na osiąganie korzyści właścicieli oraz korzyści własnych sprzężonych z korzyściami dla właścicieli,

- funkcja służebna jako podmiotu społecznego, mającego jak najlepiej służyć społeczeństwu i pełnić określone powinności społeczne.

Odpowiedzialność banku względem różnych interesariuszy będzie oznaczała co innego, co obrazuje rysunek 1.

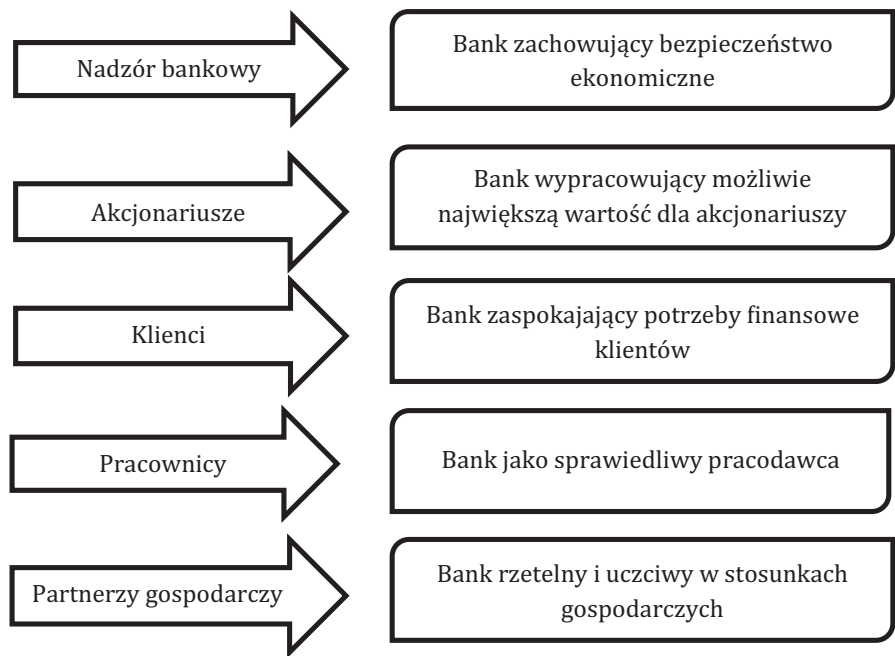

RYSUNEK 1. Odpowiedzialność banku a potrzeby interesariuszy

Źródło: Opracowanie własne na podstawie [Korenik 2009, s. 8].

Społeczna odpowiedzialność instytucji finansowych jest jednym z najważniejszych zagadnień we współczesnej gospodarce światowej. Pieniądz jest bowiem dobrem wspólnym, a obroty pieniężne powinny charakteryzować się bezpieczeństwem i wzajemnym zaufaniem uczestników rynku pieniężnego. Reputacja i zaufanie do instytucji finansowych zostały mocno nadszarpnięte kryzysem z 2008 roku. Banki goniąc za zyskiem udzielały ryzykownych kredytów hipotecznych 
oraz upowszechniały bardzo ryzykowne transakcje terminowe, które były oparte na zasadach wzajemnych. Działania te naraziły klientów banków na poważne straty. W związku z kryzysem nastąpił spadek zaufania do instytucji bankowych.

W ostatnim czasie specjaliści zauważyli niebezpieczne związki pomiędzy nasileniem aktywności w kwestii społecznej odpowiedzialności biznesu a chęcią odwrócenia uwagi od nieetycznych działań instytucji finansowych. Przykładem takich działań mogą być banki islandzkie, które w ramach CSR znacznie zaangażowały się w działalność filantropijną [www.nie nieodpowiedzialni.pl], sponsorowały wydarzenia sportowe, prowadziły działalność charytatywną itp. Sponsoring prowadzony na tak szeroką skalę przyczynił się do wzrostu zaufania do banków, a zarazem osłabił czujność społeczności islandzkiej. W tym samym czasie zarządzający bankami prowadzili ryzykowną politykę, której finałem była niewypłacalność i bankructwo trzech największych banków w Islandii. Konsekwencją załamania sektora finansowego były masowe bankructwa firm i konsumentów, wysoki poziom bezrobocia, utrata oszczędności i zahamowanie inwestycji, olbrzymi wzrost zagranicznego zadłużenia, zarówno prywatnego jak i publicznego, wzrost podatków i obniżenie wydatków socjalnych, a także emigracja wysoko wykwalifikowanych pracowników. Islandzkie banki okazały się nieodpowiedzialne, ponieważ zaniedbały podstawowe obowiązki polegające na ograniczaniu ryzykownych i szkodliwych działań w biznesie.

Wyniki badania CSR in the European Banking Sektor, przeprowadzonego w 2006 roku uwidoczniły działania najczęściej stosowane w sektorze bankowym (badania obejmowały 17 banków z 8 krajów europejskich). Z wyników można wywnioskować, że:

- $\quad$ strategicznymi obszarami działalności dla banków są: pracownicy oraz odpowiedzialność za środowisko naturalne i kwestie społeczne,

- działaniami względem środowiska i społeczeństwa są: akcje charytatywne oraz sponsoring,

- wykorzystywanymi instrumentami CSR są: kodeksy etyczne i współpraca z interesariuszami [Dobre partnerstwo... 2014].

Częstym zjawiskiem jest nadużywanie pojęcia CSR oraz przypisywanie mu działań, które w rzeczywistości mają inny charakter ${ }^{1}$ dlatego np. sponsoring jakiegoś przedsięwzięcia to raczej działalność z zakresu marketingu niż rzeczywistego przekonania o społecznej odpowiedzialności biznesu. Warto nadmienić, iż od 2010 roku obserwowano wzmożone przejmowanie przez banki i inne instytucje finansowe ideologii CSR. Można wyróżnić różne postawy, które występują przy przejmowaniu przez bank CSR. Dla niektórych banków CSR to moda, dzięki

1 Kubacki G., Eksperci: instytucje finansowe często mylą CSR z marketingiem czy reklamą, http://biznes.pl/wiadomosci/raporty/eksperci-instytucje-finansowe-czesto-myla-csrz-ma,5645812,1,5585484,301,news-detal.html. 
której, poprzez wybiórcze i pozorne działania o charakterze społecznym, można zyskać przychylność opinii publicznej, dla innych jest to coś nierealistycznego, sprzecznego z zasadami współczesnej gospodarki, ale może być również czymś realnym i potrzebnym, przekładającym się na wymierne korzyści.

W naukach ekonomicznych istnieje wiele poglądów odnośnie CSR. Przez wiele lat banki nie czuły się zobowiązane do podejmowania działań w kwestii społecznej odpowiedzialności biznesu. Obecnie doświadczone kryzysem gospodarczym środowiska naukowe oraz organy Unii Europejskiej twierdzą, że sektor bankowy w działaniach powinien być mocno skorelowany z ideą CSR.

$\mathrm{Na}$ rynku bankowym coraz większą rolę odgrywają niematerialne składniki banku, które pozwalają umocnić pozycję rynkową. Postępujące procesy konsolidacyjne są powodem wzrostu konkurencyjności na rynku bankowym. Banki przez działania pozwalające na zwiększenie dobrego wizerunku jednostki mogą zyskać cenne zaufanie klientów, które zostało znacznie utracone przez niedawny kryzys finansowy. Odpowiednio wykreowana marka i wizerunek pozwalają na lepsze pozycjonowanie banku i jego usług na rynku. Wizerunek jest częścią strategii długookresowej, co powoduje, że powinien być nieodłączną częścią misji banku [Szwacka-Mokrzycka 2010, s. 284].

\section{DZIAŁANIA BANKÓW SPÓŁDZIELCZYCH W OBSZARZE CSR}

Banki spółdzielcze są szczególnymi podmiotami ekonomii społecznej. W prowadzeniu działalności, oprócz celu ekonomicznego, ważnym elementem ich funkcjonowania jest spełnianie misji społecznej. Funkcjonowanie banków spółdzielczych nie opiera się jedynie na maksymalizacji zysku przy jednoczesnej minimalizacji ryzyka, jak to jest w przypadku banków komercyjnych, ale dzięki realizacji zadań zaspokajają potrzeby udziałowców i społeczności lokalnej.

Misją banków spółdzielczych jest działanie nastawione na zaspokajanie potrzeb swoich członków, klientów oraz rozwój środowiska lokalnego. Misja ta jest realizowana poprzez indywidualne podejście do klienta oraz zdolność do przekształceń.

Większość banków spółdzielczych przy definiowaniu misji banku podaje zaspokojenie potrzeb finansowych klientów, dbałość o społeczność lokalną oraz rozwój i poprawę świadczonych usług (tabela 1). Podstawowym atutem banków spółdzielczych jest ich lokalny charakter, który może być wykorzystany np. w formowaniu wielofunkcyjnego rozwoju wsi, w rozwoju przedsiębiorczości, w rozwiązywaniu problemu bezrobocia na wsi, ochrony środowiska oraz innych działaniach, służących aktywizacji gospodarczej i społecznej wsi [Szafrańska 2006, s. 214]. Jako tradycyjne pole zainteresowania sektora banków spółdzielczych uznaje się rolnictwo i obszary wiejskie. Banki spółdzielcze nie uczyniły jeszcze ostatniego kroku w stosunku do sektora rolnego, wprost przeciwnie postrzegają 
go jako obszar możliwego przyszłego wzrostu rynkowego. Banki spółdzielcze realizują wiele zadań przez różnego rodzaju działania na gruncie lokalnym. Przykłady działań społecznie odpowiedzialnych prowadzonych przez banki spółdzielcze można podzielić na inicjatywy na rzecz najbiedniejszych, najbardziej potrzebujących oraz na inicjatywy w zakresie ochrony środowiska naturalnego.

TABELA 1. Przykładowe definicje misji banków spółdzielczych

\begin{tabular}{|l|l|}
\hline Bank & Misja \\
\hline Bank Spółdzielczy w Płońsku & $\begin{array}{l}\text { Misją Banku Spółdzielczego w Płońsku jest zdobywanie } \\
\text { i utrzymanie zaufania i lojalności klientów oraz zapewnie- } \\
\text { nie satysfakcji pracownikom i udziałowcom. }\end{array}$ \\
\hline $\begin{array}{l}\text { Powiatowy Bank Spółdzielczy } \\
\text { w Sokołowie Podlaskim }\end{array}$ & $\begin{array}{l}\text { Efektywnie, profesjonalnie i kompleksowo zaspokaja po- } \\
\text { trzeby finansowe klientów indywidualnych, instytucjonal- } \\
\text { nych i samorządowych. }\end{array}$ \\
\hline ESBANK Bank Spółdzielczy & $\begin{array}{l}\text { Misją Banku jest być najbliższym i zaufanym partnerem } \\
\text { swoich Klientów, powiernikiem oszczędności, świadczącym } \\
\text { kompleksowe, profesjonalne i efektywne usługi finansowe. }\end{array}$ \\
\hline Piastowski Bank Spółdzielczy & Rozwijamy się wspólnie dzięki zaufaniu \\
\hline
\end{tabular}

Źródło: Opracowanie własne.

\section{WYNIKI BADAŃ}

Celem artykułu jest rozpoznanie wykorzystywanych przez banki działań do szerzenia idei społecznej odpowiedzialności biznesu oraz określenie ich znaczenia w opinii zarządzających bankami spółdzielczymi. Uzyskane informacje dotyczyły działań podejmowanych przez banki takich jak: posiadanie strony banku na portalu społecznościom, organizowanie konkursów i programów lojalnościowych dla klientów banków, sponsoring, współpraca banku z mediami, organizacja przez bank seminariów, odczytów, szkoleń i konferencji, finansowanie i wspieranie instytucji socjalnych i oświatowych, informowanie o wynikach i działalności banku etc.

Z przeprowadzonych badań wynika, że wszystkie badane banki brały udział w finansowaniu i wspieraniu instytucji socjalnych i oświatowych (100\% badanych). Jedynie 9 banków wykorzystywało nowoczesne formy komunikowania się ze społecznością lokalną. Niewielki odsetek badanych (28,57\%) stosował inne niż proponowane działania. Wśród wymienianych znalazły się: patronat nad szkolnymi kasami oszczędnościowymi (SKO), wspieranie inicjatyw lokalnych, system komunikacji multimedialnej, doradztwo gospodarcze i w zakresie funduszy unijnych oraz wewnętrzna telewizja. Pozostałe działania były realizowane w takim samym stopniu. Jak wynika z danych w tabeli 2 banki bardzo chętnie angażowały 
się w działania związane ze CSR. Wynika to z odpowiedzialności banku jako instytucji zaufania publicznego oraz samej idei spółdzielczości. Dla banków spółdzielczych priorytetem jest pomoc społeczności lokalnej, która objawia się jako wsparcie organizacji oświatowych czy też objęcie mecenatem miejscowych szkół i organizacji sportowych.

TABELA 2. Najczęściej stosowane przez banki inicjatywy społecznościowe i ich ważność $(\mathrm{N}=140)$

\begin{tabular}{|l|c|c|}
\hline Inicjatywa & Udział [\%] & Ważność \\
\hline Posiadanie strony banku na portalu społecznościom & 32,14 & 3,60 \\
\hline $\begin{array}{l}\text { Organizacja konkursów i programów lojalnościowych dla klientów } \\
\text { banków }\end{array}$ & 92,86 & 4,19 \\
\hline Sponsoring & 92,86 & 4,41 \\
\hline Współpraca z mediami & 92,86 & 4,31 \\
\hline Organizacja seminariów, odczytów, szkoleń i konferencji & 67,86 & 3,76 \\
\hline Udział w akcjach społecznościowych & 89,29 & 4,23 \\
\hline Finansowanie i wspieranie instytucji socjalnych i oświatowych & 100,00 & 4,25 \\
\hline Informowanie o wynikach i działalności banku & 92,57 & 4,37 \\
\hline Inne & 28,57 & 4,50 \\
\hline
\end{tabular}

Źródło: Badania własne.

Działania najczęściej stosowane przez banki zostały wysoko ocenione, jednak jako najważniejsze według zarządzających bankami są inne środki promowania CSR (tabela 2). Spośród proponowanych najważniejszymi zostały uznane działania sponsoringowe oraz finansowanie i wspieranie instytucji socjalnych i oświatowych. Mniej ważnymi działaniami okazały się organizowanie seminariów, odczytów, szkoleń i konferencji oraz posiadanie strony na portalu społecznościowym.

Biorąc pod uwagę podział banków według sumy bilansowej, badania wykazały, że w bankach o sumie bilansowej do $200 \mathrm{mln}$ zł zaproponowane działania związane z CSR wykorzystuje się w takim samym stopniu (rysunek 2). Działaniami o najmniejszym zainteresowaniu banków z tej grupy była organizacja szkoleń i seminariów oraz obecność na portalach społecznościowych. Jedynie 3 banki zadeklarowały stosowanie innych niż wymienione działań w sferze społecznej odpowiedzialności biznesu.

W kolejnej grupie znalazły się banki o sumie bilansowej od 200 do $250 \mathrm{mln}$ zł (rysunek 3). Wśród tej grupy banków najczęściej wykorzystywanymi działaniami okazały się działania sponsoringowe, kontakt z mediami, informacje o wynikach z działalności oraz finansowanie placówek oświaty $(15,2 \%)$. Najrzadziej wykorzystywanymi działaniami okazały się, podobnie tak jak we wcześniejszej grupie, posiadanie strony na portalu społecznościowym $4,3 \%$ oraz organizacja semina- 


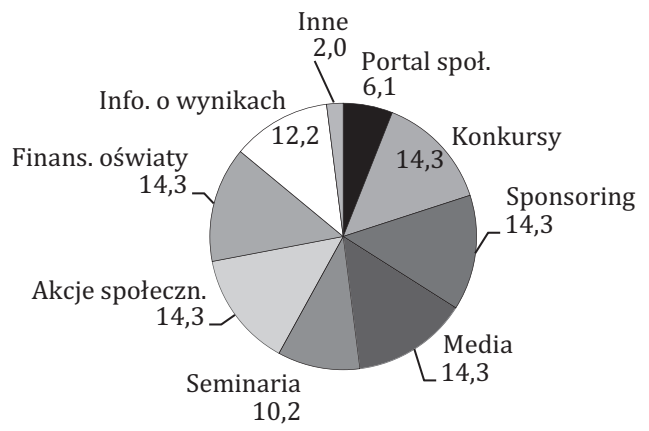

RYSUNEK 2. Rodzaje i struktura wykorzystywanych inicjatyw społecznych w bankach o funduszach własnych do $200 \mathrm{mln}$ zł [\%] - Kwartyl I

Źródło: Badania własne.

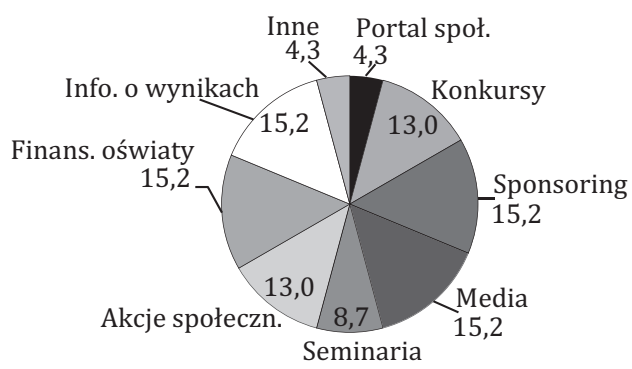

RYSUNEK 3. Rodzaje i struktura wykorzystywanych inicjatyw społecznych w bankach o funduszach własnych od 200 do $250 \mathrm{mln}$ zł [\%] - Kwartyl II

Źródło: Badania własne.

riów i szkoleń 8,7\%. Dwa banki zadeklarowały stosowanie innych niż proponowane inicjatyw społecznych.

Wśród banków o aktywach od 250 do 400 mln zł, przedstawionych na rysunku 4, zdecydowanie najczęściej wykorzystywanym działaniem było finansowanie i wspieranie instytucji socjalnych i oświatowych oraz konkursy i programy lojalnościowe dla klientów banku (16,7\%). W przeciwieństwie do grupy banków o sumie bilansowej od 200 do $250 \mathrm{mln}$ zł działania sponsoringowe znalazły się wraz z organizacją seminariów i szkoleń w grupie najmniej wykorzystywanych inicjatyw. W badanej grupie żaden z banków nie prowadził działań na portalu społecznościowym.

Ostatnią grupę tworzyły banki o aktywach przekraczających 400 milionów złotych. Badania wykazały, że banki o największych aktywach w takim samym stopniu stosowały proponowane działania CSR (rysunek 5). Podobnie jak w po- 


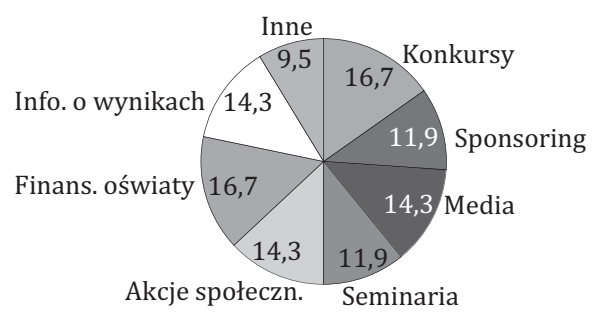

RYSUNEK 4. Rodzaje i struktura wykorzystywanych inicjatyw społecznych w bankach o funduszach własnych od 250 do $400 \mathrm{mln}$ zł [\%] - Kwartyl III

Źródło: Badania własne.

przednich grupach najmniej wykorzystywanym działaniem była organizacja seminariów i szkoleń 10,4\% oraz działania na portalu społecznościowym. Jedank była to grupa, w której najwięcej banków deklarowało obecność na portalach społecznościowych (8,3\%). Jedynie jeden bank zadeklarował wykonywane innych działań związanych ze społeczną odpowiedzialnością biznesu.

Na podstawie średniej ocen ważności działań CSR podjętych przez banki (rysunek 6) można stwierdzić, że dla banków o sumie bilansowej od 250 do $400 \mathrm{mln}$ zł działania w sferze społecznej odpowiedzialności biznesu były najważniejsze z całej próby badawczej. Działania te okazały się najmniej ważne dla banków o najmniejszej sumie bilansowej, natomiast grupa podmiotów o sumie bilansowej od 200 do 250 mln wykazywała średnio większą ważność dla podejmowanych działań społecznych niż banki o największej sumie bilansowej.

Z przeprowadzonych badań wynika, że działania na portalu społecznościowym były najważniejsze dla zarządzających bankami o największej sumie bilansowej. Banki wysoko oceniły inicjatywę organizacji konkursów oraz programów lojalnościowych dla klientów. Te działania najwyżej oceniły banki o aktywach od

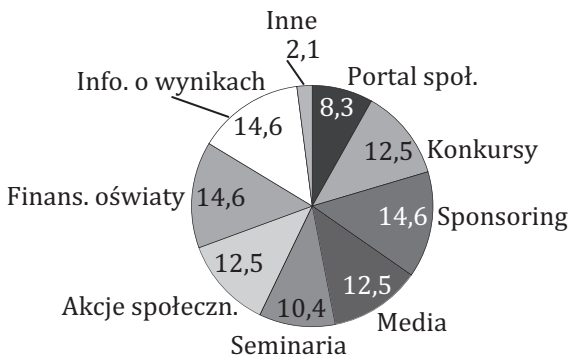

RYSUNEK 5. Rodzaje i struktura wykorzystywanych inicjatyw społecznych w bankach o funduszach własnych powyżej $400 \mathrm{mln}$ zł [\%] - Kwartyl IV

Źródło: Badania własne. 


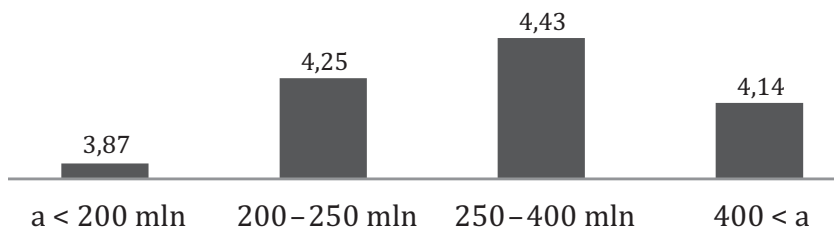

RYSUNEK 6. Średnia ocena ważności wykorzystywanych działań według sumy bilansowej banku (a)

Źródło: Badania własne.

250 do 400 mln zł, najmniej ważna była ta inicjatywa dla banków o największej sumie bilansowej. Większe zróżnicowanie w ocenach jest widoczne w ocenie działań o charakterze sponsoringowym. W tym przypadku ta inicjatywa była najważniejsza dla banków o najmniejszej i największej sumie bilansowej. Kolejnym ocenianym działaniem była współpraca z mediami. W przypadku oceny tej inicjatywy można dostrzec tendencję malejącą co do ważności tego działania. Kontakt z mediami był najważniejszy dla banków o najmniejszej sumie bilansowej i wraz ze wzrostem kwoty aktywów banku jego znaczenie malało. Co ciekawe, podobną tendencję wykazywała ocena udziału banków w akcjach społecznościach. Jednak w tym przypadku należy zwrócić uwagę, że dla banków o funduszach własnych poniżej 200 milionów to działanie było wyżej oceniane niż przez inne banki. Jedną z najniżej ocenionych inicjatyw społecznych była organizacja seminariów, odczytów, szkoleń i konferencji. To działanie okazało się najważniejsze dla banków o aktywach powyżej 400 milionów. Kolejnymi ocenianymi działaniami było finansowanie i wspieranie instytucji socjalnych i oświatowych oraz informowanie o wynikach i działalności banku. Banki o aktywach o 200 milionach oraz o aktywach od 250 do 400 milionów wysoko oceniły inicjatywę finansowania oświaty, natomiast informowanie o wynikach banku już zdecydowanie niżej. Odwrotnie przedstawia się sytuacja pozostałych grup banków. Dla których informowanie o wynikach finansowych miało większe znaczenie niż finansowanie oświaty. Spośród banków deklarujących podejmowanie innych niż wymienione inicjatywy społeczne, najwyższe oceny przyznały banki o aktywach od 250 do 400 milionów.

\section{WNIOSKI}

W opracowaniu przedstawiono charakterystykę koncepcji CSR w odniesieniu do sektora bankowości spółdzielczej w Polsce. Dokonane badania miały charakter fragmentaryczny, dlatego nie należy uogólniać wyników na cały sektor bankowy. Na podstawie przeprowadzonych badań należy stwierdzić, że:

1. Banki spółdzielcze wspierają i realizują działania związane ze społeczną odpowiedzialnością biznesu. Banki te są głównymi organizacjami realizującymi 
założenia CSR, która jest wpisana w ideę spółdzielczości. W swej działalności banki spółdzielcze nieustannie rozwijają model ekonomii społecznej, który jest ukierunkowany na rozwój społeczności lokalnej i regionalnej.

2. Działaniem społecznym najwyżej ocenionym przez większość respondentów, zaproponowanym w badaniu ankietowym, był sponsoring. Przy czym w trzech bankach najwyżej ocenianymi działaniami były inicjatywy nie wymienione w kwestionariuszu ankietowym. Na uwagę zasługuje fakt, że pozostałe z zaproponowanych działań w sferze CSR zostały wysoko ocenione przez zarządzających bankami spółdzielczymi.

3. Działanie banku na portalu społecznościowym było wykorzystywane jedynie przez jedną trzecią badanej populacji i zostało nisko ocenione w kwestii ważności stosowanych działań CSR przez banki spółdzielcze. Wyniki badania ankietowego potwierdzają tezę, że banki spółdzielcze w ograniczonym zakresie wykorzystują nowoczesne narzędzia służące utrzymaniu relacji z klientem.

\section{Spis literatury}

BALINA R. 2014: Społeczna odpowiedzialność biznesu (CSR) na przykładzie banków spółdzielczych, Zarządzanie Finansami i Rachunkowość, t. 2, nr 4, s. 51-60.

Dobre Partnerstwo - Teoria a praktyka: Jak instytucje finansowe budują współpracę na korzyść lokalnych społeczności, Instytut Jagielloński, Warszawa 2014.

FILEK J., 2008: Przyczyny małego zainteresowania ideą CSR w Polsce, [w] M. Bąk, P. Kulawczuk, (red.), Społeczna odpowiedzialność biznesu w małych i średnich przedsiębiorstwach: praca zbiorowa. Instytut Badań nad Demokracją i Przedsiębiorstwem Prywatnym.

http://www.nienieodpowiedzialni.pl/Nieodpowiedzialno-za-zas-on-CSR_2_38_1.html, (dostęp: 15.01.2017).

IDASZ-BALINA M., BALINA R., 2016: Narzędzia CSR w kreowaniu wizerunku banku spółdzielczego. Zarządzanie Finansami i Rachunkowość, t. 4, nr 3, s. 69-79.

JUSZCZYK S., BALINA R., 2016: Poziom i struktura wydatków prospołecznych banków spółdzielczych w zależności od płci prezesa zarządu. Problemy Drobnych Gospodarstw Rolnych, 3, s. 27-43.

KORENIK D. 2009: O roli służebnej banków komercyjnych, Wyd. UE we Wrocławiu, Wrocław.

KUBACKI G., Eksperci: instytucje finansowe często mylą CSR z marketingiem czy reklamą, http://biznes.pl/wiadomosci/raporty/eksperci-instytucje-finansowe-czesto-mylacsr-z-ma,5645812,1,5585484,301,news-detal.html (dostęp: 15.01.2017).

SGS Polska: Barometr CSR, Wybrane wyniki pierwszej edycji badań opinii publicznej, 2013 r., s. 2-3, http://www.doradztwocsr.pl/pdf/BAROMETR_CSR_2013_Broszura_ konferencyjna.pdf, (dostęp:13.12.2014) 
SZAFRAŃSKA M. 2006: Rola banków spółdzielczych w rozwoju rolnictwa i obszarów wiejskich, Problemy Rolnictwa Światowego. Szkoła Główna Gospodarstwa Wiejskiego, 15, s. 213-220.

SZWACKA-MOKRZYCKA J. 2010: Znaczenie wizerunku w budowaniu pozycji konkurencyjnej banków, Zeszyty Naukowe Szkoły Głównej Gospodarstwa Wiejskiego w Warszawie, Polityki Europejskie, Finanse i Marketing, 4 (53), s. 278-286.

\section{THE NATURE AND SIGNIFICANCE OF CSR TOOLS IN THE OPINION OF THE COOPERATIVE BANKS MANAGERS}

Abstract. The purpose of the research was to present solutions used by cooperative banks in implementation of the principles related to the idea of corporate social responsibility and their importance in the opinion of the managers of cooperative banks. The research covered 140 cooperative banks, which accounted for $24.6 \%$ of all cooperative banks operating in Poland as of 30 June 2016. Based on the analyzes, it was found that cooperative banks have supported and implemented corporate social responsibility rules and tools since the beginning of their activity. In addition, the respondents pointed out that sponsorship is the most important form of communication with the local community, but cooperative banks, in addition to traditional CSR tools, also employ a number of additional tools, which, in the executives' opinion, are highly relevant to their operations.

Keywords: CSR, corporate social responsibility, cooperative bank 